\title{
PROSTATE CARCINOMA WITH NEUROENDOCRINE DIFFERENTIATION: CASE REPORT AND LITERATURE REVIEW
}

Raquel Civolani Marques Fernandes, Marcus de Medeiros Matsushita, Thais Mauad and Paulo Hilário Nascimento Saldiva

FERNANDES RCM et al. - Prostate carcinoma with neuroendocrine differentiation: case report and literature review. Rev. Hosp. Clín. Fac. Med. S. Paulo 56(5):153-158, 2001.

Neuroendocrine differentiation in prostatic carcinomas generally confers a more aggressive clinical behavior and less favorable prognosis than usual prostatic carcinomas. In this manuscript, we report a case of a 58-year-old man with prostatic carcinoma who died 1 year after initial diagnosis. Autopsy showed a disseminated prostatic carcinoma with neuroendocrine differentiation. There were metastasis to the spleen, an organ infrequently involved by disseminated epithelial neoplasms. Neuroendocrine differentiation was demonstrated by immunohistochemical studies in the biopsy and autopsy material.

DESCRIPTORS: Prostatic carcinoma. Neuroendocrine differentiation. Autopsy. Immunohistochemistry. Splenic metastasis.

Prostate carcinomas usually occur after the age of 50, with a higher incidence after the age of $70^{1}$. They are the most common neoplasia in men and the second highest cause of death by cancer in the United States, second only to lung cancer $^{2}$. The death rate resulting from prostate carcinoma has been growing in Brazil, with an estimated 14800 new cases and 6850 deaths for the year $2000^{3}$.

About $95 \%$ of the malignant prostatic neoplasms are adenocarcinomas ${ }^{2}$. Neuroendocrine cells are abundant in the prostate and are diffusely distributed throughout the organ at birth ${ }^{4,5}$. According to the literature, depending on the sensitivity of the technique applied, traces of neuroendocrine differentiation can be found in the adenocarcinomas in $10 \%$ to $100 \%$ of the cases ${ }^{6}$.
The cases of malignant neoplasia of the prostate with neuroendocrine differentiation have poorer prognosis (35\% survival rate in 2 years) than cases without it $(97 \%$ survival rate in 2 years $)^{7,8}$.

In the following report, we describe a case of a patient having prostatic adenocarcinoma with extensive neuroendocrine differentiation and rapid evolution to death (12 months after diagnosis); the autopsy revealed extensive dissemination of the neoplasia.

From the Department of Pathologic Anatomy, Hospital das Clínicas, Faculty of Medicine, University of São Paulo.

\section{CASE REPORT}

A white male patient, 58 years old, was admitted to another medical service in January 1998 complaining of a decrease in urinary flow rate and an acute episode of urinary retention. There he underwent transurethral resection (TUR) in March 1998 for de-obstruction of the excretory tract. A prostate adenocarcinoma with PSA serum values of $33 \mathrm{ng} / \mathrm{ml}$ was discovered from this procedure. In May of the same year, the patient was admitted to this service and underwent an ultrasound examination, which revealed a prostate measuring $4.7 \mathrm{x}$ $4.1 \times 3.8 \mathrm{~cm}$ with an estimated weight of $40 \mathrm{~g}$. The patient complained of pelvic and lumbar pain. Bone scintillography in June 1998 showed alterations suggesting a secondary compromise by the neoplasia of the 
sternocostal articulation, sternum, vertebral bodies (C1-C2; T4-T5; L2; L5-S1), $1^{\text {st }}$ right-anterior costal arc, $3^{\text {rd }}, 4^{\text {th }}, 7^{\text {th }}$ and $9^{\text {th }}$ right-posterior costal arcs, $3^{\text {rd }}$ and $8^{\text {th }}$ leftposterior costal arcs, left sacroiliac ligament, bilateral ischia, and proximal third of the femur. A bilateral subcapsular orchiectomy was executed (July 1998) with anatomic-pathologic results of "testicles within normal limits for age". In November of the same year, a new palliative TUR (15 g) was executed revealing "prostate carcinoma with a Gleason score of $10(5+5)$ in 100\% of the fragments, and presence of perineural invasiveness." Two days after the surgical procedure, the patient presented hematuria, tachycardia, and postural hypotension, and underwent hemostasia of the bleeding vessels of the prostatic compartment and a transfusion of erythrocyte concentrate. Beyond this date, the patient evolved into generalized weakness and chronic anemia, and was sent twice to the emergency room to receive erythrocyte concentrate and support therapy. At the end of February 1999, the patient came once more to our hospital with paleness and significant pancytopenia, developed a new episode of hematuria, experienced a lowering of the consciousness level, and died on March 1, 1999.

An autopsy was indicated to identify the level of dissemination of the neoplasia. During necropsy, extreme cachexia was externally evident. The prostate was enlarged, with the neoplasia measuring $6 \mathrm{~cm}$ on its largest axis, hardened, whitish, showing a large central necrotic area, infiltrating the rectum and bladder. In the thoracic cavity, bilateral serous effusion was found with multiple paraortic and parietal pleura metastases. The lungs had multiple tumor massesthe largest measuring $2.5 \mathrm{~cm}$-close to the pleural surface. A number of hilar lymph nodes were macroscopically found to be compromised by the neoplasia. In the abdominal cavity, no free fluids were seen, and the liver, spleen, and adrenal glands had metastases measuring between 5 and $2 \mathrm{~cm}$.
At microscopy of the primary prostatic tumor, poorly differentiated adenocarcinoma was seen, which was characterized by solid cell proliferation with intense pleomorphism and plump nuclei showing intense hyperchromasia and many mitotic figures (Fig. 1). In the metastases, the tumor had a solid trabecular displacement, with nuclear molding resembling that of neuroendocrine neoplasia (Figs. 2 and 3 ).

The immunohistochemical panel was done for the primary prostatic tumor and the metastases, revealing both to be diffusely positive for prostatic specific antigen (PSA) (DAKO M0750, Glostrup, Denmark) and neuron-specific enolase
(NSE) (DAKO M0873, Glostrup, Denmark), focally positive for chromogranin A (DAKO M0869, Glostrup, Denmark) and negative for synaptophysin (DAKO M0776, Glostrup, Denmark). The tumor marker panel was applied retrospectively to the histologically prepared material obtained with the last TUR, producing results similar to those of the autopsy (Figs. 4 and 5).

\section{DISCUSSION}

The current report describes a case of prostatic carcinoma that had an extremely aggressive biological behavior.

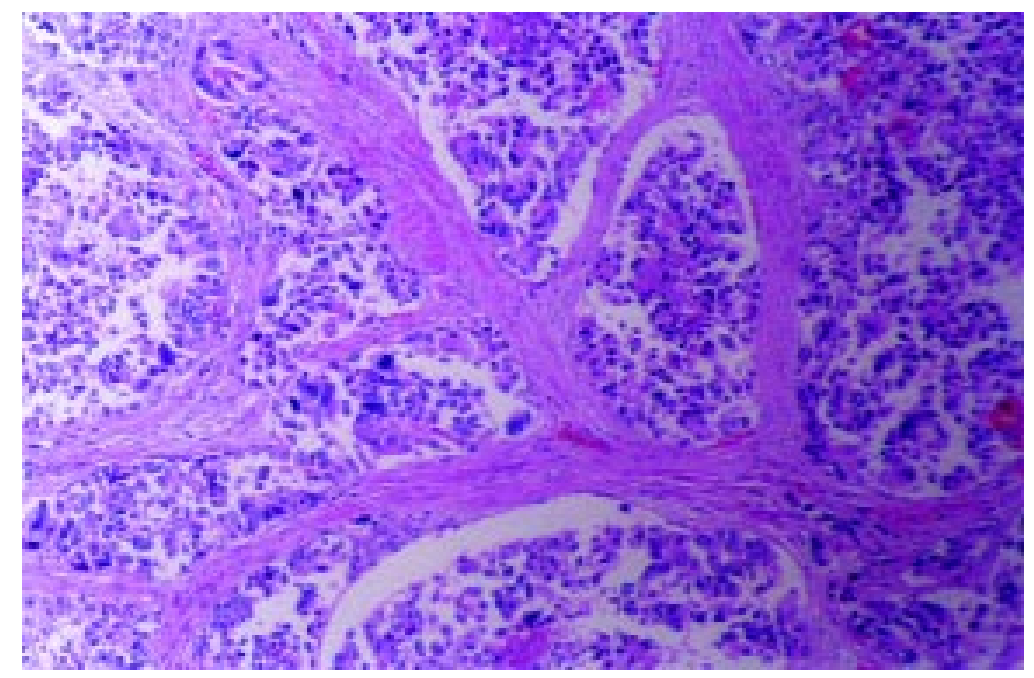

Figure 1 - Poorly differentiated prostatic adenocarcinoma (hematoxylin - eosin; 100x).

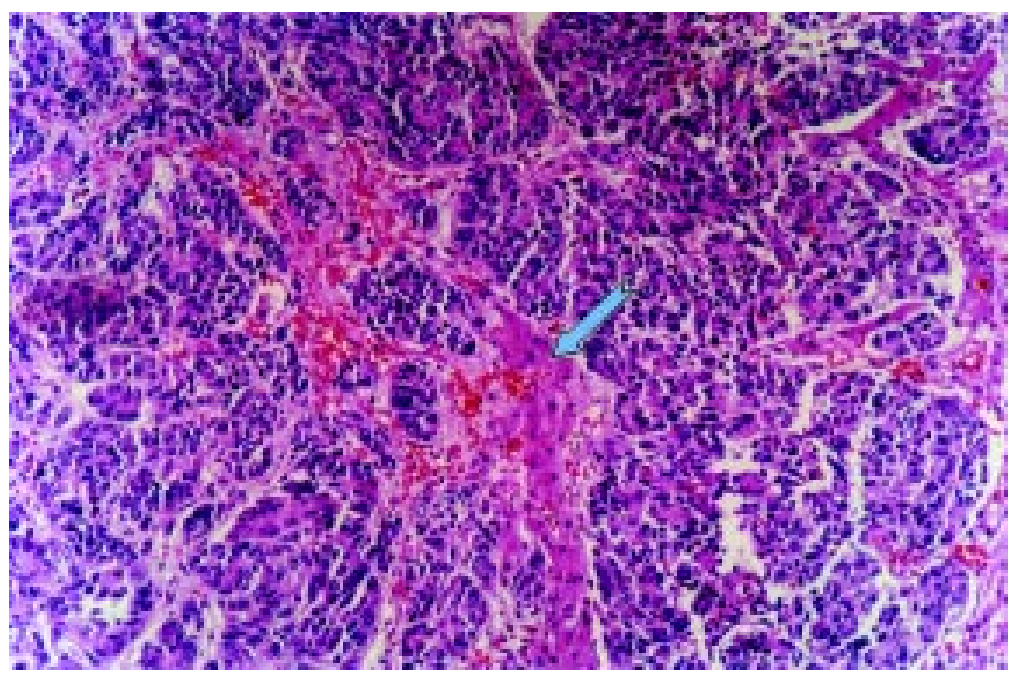

Figure 2 - Liver metastasis. Solid tumor with trabecular displacement. The neoplasia compresses permeating hepatocellular chain (arrow) (hematoxylin - eosin; 100x) 


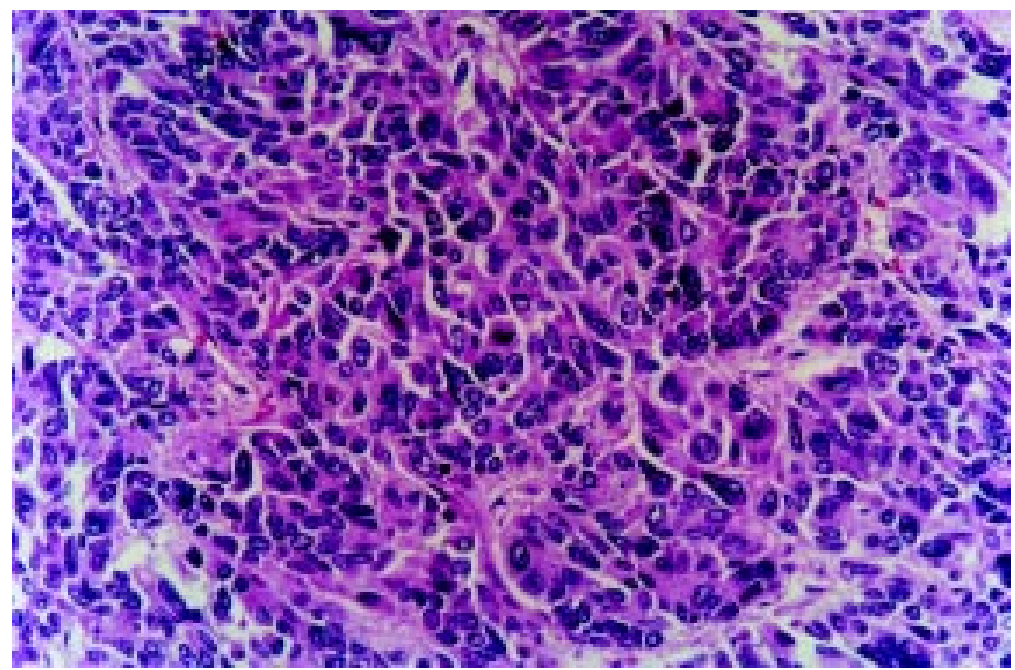

Figure 3 - Detail of the previous picture. Note the intense occurrence of atypical cells, mitoses and certain degree of nuclear molding (hematoxylin - eosin; 200x).

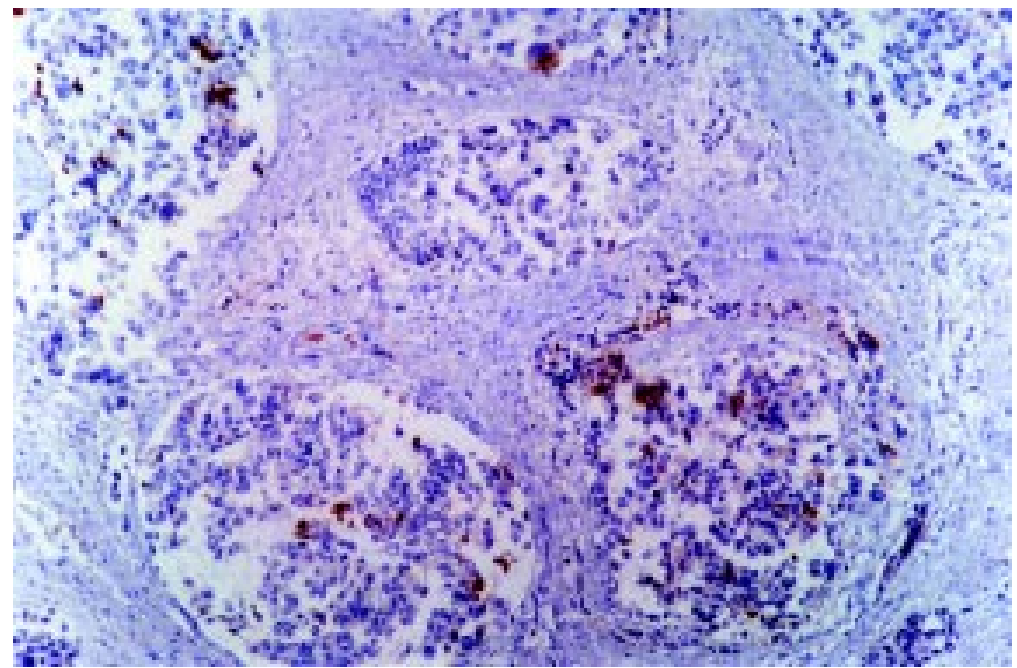

Figure 4 - Immunohistochemical examination using anti-chromogranin A antibody demonstrating focal positivity of neuroendocrine cells in the prostate (100x).

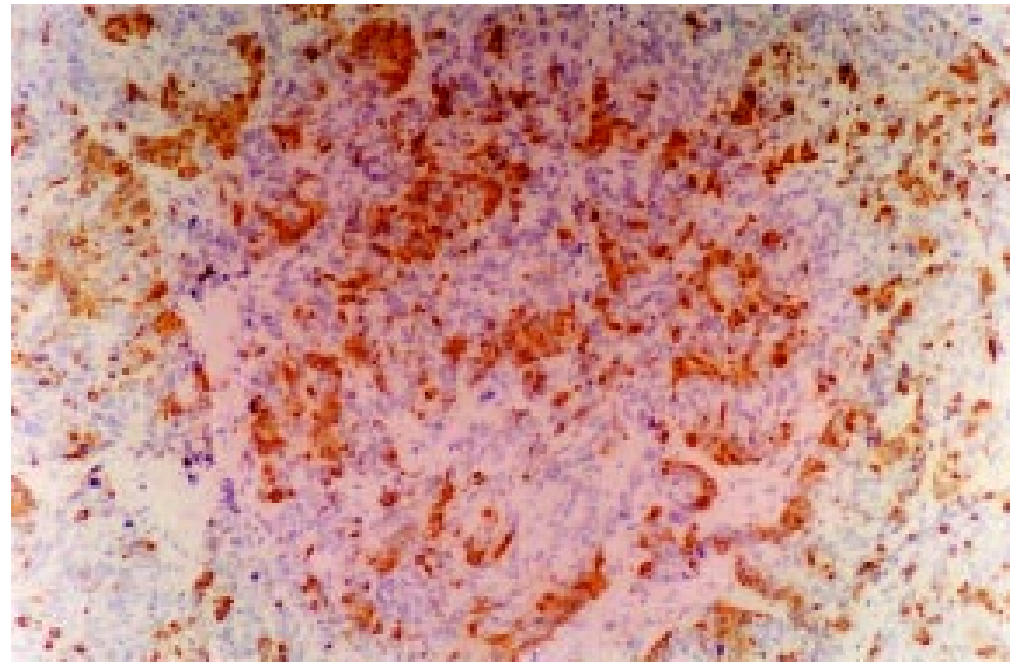

Figure 5 - Immunohistochemical examination in the liver metastasis showing intense positivity of neoplastic cells for anti-chromogranin A antibody (100x).
Only 1 year elapsed between the initial diagnosis and the patient's death with disseminated neoplasia. The histopathological examination revealed a poorly differentiated carcinoma with extensive neuroendocrine differentiation, as determined from immunohistochemical examination. Cases of malignant neoplasia of the prostate with neuroendocrine differentiation have a poorer prognosis ( $35 \%$ survival rate in 2 years) than cases without neuroendocrine differentiation $(97 \% \text { survival rate in } 2 \text { years })^{7,8}$, in addition to being associated with an independent androgen state.

The cells of the diffuse neuroendocrine system (formerly known as the APUD system) are located centrally in the human body (hypophysis, hypothalamus, and pineal) and peripherally (lung, gastrointestinal tract, thyroid, ducts, and epithelium of the prostatic acini among other organs) ${ }^{6}$. It is generally believed that in the prostate, these cells are involved in regulation of growth and development of the organ, as well as regulation of the secretory processes of the mature gland ${ }^{6}$. Prostatic carcinoma can present diverging differentiation of neuroendocrine phenotypes in the form of small cell neuroendocrine carcinoma (rare variant, encompassing $5 \%$ to $2 \%$ of all prostatic carcinomas $)^{9}$ or of carcinoid-like tumors. It is also believed that pure prostatic neuroendocrine neoplasia derives from multipotent stem cells manifested in the organ ${ }^{10}$. Much more common is the focal neuroendocrine differentiation in prostatic adenocarcinomas, which can be more exuberant in $10 \%$ of the adenocarcinomas ${ }^{11}$. According to the literature, depending on the method used, from $10 \%$ to $100 \%$ of the prostate carcinomas present clusters of neuroendocrine differentiation ${ }^{6}$. More rarely, two different forms of neuroendocrine differentiation can occur in the same patient with prostate neoplasia ${ }^{12}$.

The degree of neuroendocrine differentiation in a conventional adeno- 
carcinoma seems to be directly related to the degree of aggressiveness of the tumor ${ }^{6}$. It is still not clear if the aggressive behavior is a reflection of the neuroendocrine differentiation or merely due to a high tumor level. It is not uncommon to observe the progression of a typical prostate adenocarcinoma with minimal or no neuroendocrine differentiation to a neuroendocrine carcinoma or a carcinoma with neuroendocrine differentiation that is unresponsive to hormone therapy ${ }^{6}$.

Although still not well defined, the reasons that might cause the poor prognosis of this histologic subtype may include active neuroendocrine cell products, such as a growth factor, and the lack of androgen receptors in the neuroendocrine cells ${ }^{13}$, which would also account for unresponsiveness to hormonal treatment. Wu et al. studied 14 cases of prostatic carcinomas that were resistant to hormonal treatment. High serum values of chromogranin A were noticed in 10 cases, while PSA remained at normal levels, and NSE was not detected. The early detection of high serum levels of chromogranin A could be an indicator for a change to a more aggressive therapy ${ }^{14}$. Jiborn et al. suggested that androgen ablation therapy might increase the selection and progression of neoplastic neuroendocrine cells ${ }^{15}$. Diaz et al. investigated the effects of the interleukins (IL)-1 1 , -2 and -6 in the chromogranin A expression, demonstrating that IL- $1 \beta$ and IL-6 increase the secretion of chromogranin A in LNCaP and DU145 cells (prostate cancer cell lines) while IL-2 decreases chromogranin A secretion. These results suggest the cytokines IL-1ß and IL-6 can influence the neuroendocrine differentiation in prostate carcinoma and could be involved in the progression of the disease $^{16}$.

Immunohistochemical examination of the neoplastic tissue is fundamental for the correct diagnosis of this histo- logic subtype of prostatic neoplasia, allowing for a number of neuroendocrine tumor markers to be used, such as in the presented case. Anti-NSE reacts with the gamma-gamma isoform of the enolase, which is commonly used as a neuroendocrine marker ${ }^{17}$. Its positivity is not totally specific, with reports of marking by anti-NSE of non-neuroendocrine tissues ${ }^{18}$. Chromogranin A, which is a component protein of the secretory granules of endocrine cells and neurons ${ }^{17}$, is much more specific than NSE. Even when all cells are not marked with its antibody, its positivity in neoplastic cells indicates neuroendocrine differentiation of an adenocarcinoma $^{18}$. Chromogranin A seems to be the best marker of blood and tissue neuroendocrine differentiation, with its serum value being used to show appearance or progression of hormone-therapy resistance in prostate carcinomas ${ }^{11}$. Synaptophysin, a calcium-binding protein, is present in the pre-synaptic vesicles of the neuron and in the neurosecretory granules of the neuroendocrine cells. Although synaptophysin is a marker for neuroendocrine differentiation, there is difficulty in the usage of its antibody, because the reactions are difficult to interpret due to its frequently meager intensity and constant background staining ${ }^{17}$. PSA (antigen of the normal prostate epithelium and its carcinomas) ${ }^{17}$, is a reliable marker in the identification of the prostate as a primary neoplastic site. Another prostate cancer marker, prostatic acid phosphatase (enzyme secreted by the prostate epithelium and present in semen as well as blood $)^{17}$ can cross-react with lung and gastrointestinal carcinoid tumors, mainly in rectal carcinoids. In cases of small cell carcinoma of the prostate without an associated adenocarcinoma element, the anti-PSA test can be negative ${ }^{19}$.

There is still no effective treatment for malignant neoplasia of the prostate with neuroendocrine differentiation.
Conventional chemotherapy directed against small cell lung tumors has been used in some cases ${ }^{20,21}$. Potential therapies directed toward neuroendocrine hormones and/or their antagonists, such as somatostatin, bombesin, and serotonin, have been receiving attention ${ }^{22}$.

In our presented case, a higher aggressiveness was confirmed not only through rapid evolution to death (1 year), but also through the extent of the metastases afflicting organs such as the spleen, which is less commonly stricken by neoplasias originating in the epithelium. The incidence of metastases of solid tumors in the spleen ranges from $1.6 \%$ to $30 \%$ in autopsy studies ${ }^{23}$. In a study conducted on 20 cases of small cell carcinoma of the prostate, there were no metastases to the spleen in any of them ${ }^{20}$. Our case has drawn our attention to the fact that evidence of neuroendocrine differentiation in prostate neoplasias should be always thoroughly researched through precise histopathological examination. It is not reasonable to propose that an immunohistochemical panel, such as the one used in our case, be incorporated to routine diagnosis for all prostate tumors; however, it should be applied in cases in which morphology indicates its need.

In cases of unusual prostatic neoplasias with uncertain prognosis, biopsy and histological diagnosis are essential, since the role of imaging is restricted to local and metastatic evaluation of the disease $^{24}$. In this scenario, the importance of the pathologist is enhanced; the pathologist can assist in establishing the prognosis and orienting precocious treatment based on more rational grounds.

\section{ACKNOWLEDGEMENTS}

The authors would like to thank Professor Dr. Luís Balthazar Saldanha for his text review and suggestions and Luís Guilherme Di Ciero Fernandes for his help in translating the text. 
FERNANDES RCM e col. - Carcinoma de próstata com diferenciação neuroendócrina: relato de caso. Rev. Hosp. Clín. Fac. Med. S. Paulo 56(5):153-158, 2001.

Os carcinomas da próstata com diferenciação neuroendócrina apresentam comportamento mais agressivo e prognóstico menos favorável que as neoplasias prostáticas usuais. No presente relato de caso é reportada a rápida evolução para o óbito de um paciente de 58 anos portador de adenocarcinoma de próstata com diferenciação neuroendócrina. A autópsia mostrou neoplasia disseminada, acometendo inclusive o baço, sítio incomum de envolvimento metastático de neoplasias de origem epitelial. A diferenciação neuroendócrina foi demonstrada por estudo imunohistoquímico em material de biópsia e autópsia.

DESCRITORES: Carcinoma de próstata. Diferenciação neuroendócrina. Autópsia. Imunohistoquímica. Metástase esplênica.

\section{REFERENCES}

1. ROBBINS SL, CONTRAN RS, KUMAR V et al. - The male genital tract. In: ROBBINS SL - Pathologic Basis of Disease. $6^{\text {th }}$ ed. Philadelphia, Saunders, 1999. p. 1029.

2. BOSTWICK DG - Neoplasms of the prostate. In: BOSTWICK DG Urologic Surgical Pathology. St. Louis, Mosby-Year Book, 1997. p.343.

3. ESTIMATIVA da incidência e mortalidade por câncer no brasil Available on the Internet: http://www.inca.org.br/epidemiologia/ estimativa2000/brasil.html. April, 2000.

4. DI SANT AGNESE PA \& DE MESY JENSEN KL - Human prostatic endocrine-paracrine (APUD) cells: distributional analysis with a comparison of serotonin and neuron-specific enolase immunoreactivity and silver stain. Arch Path Lab Med 1985;109:607.

5. ABRAHAMSSON PA, WADSTROM LB, ALUMETS J et al. - Peptidehormone and serotonin-immunoreactive cells in normal and hyperplastic prostate glands. Path Res Pract 1986;181:675.

6. DI SANT'AGNESE PA - Neuroendocrine differentiation in human prostatic carcinoma. Hum Pathol 1992;23(3):287-296.

7. COHEN RJ, GLEZERSON G, HAFFesie $Z$ et al. - Prostatic carcinoma: histological and immunohistological factors affecting prognosis. Br J Urol 1990;66:405-410.
8. GLEZERSON G \& COHEN RJ - Prognostic value of neuro-endocrine cells in prostatic adenocarcinoma [abstract]. J Urol 1991;145:296.

9. HELPAP B, KÖLLERMANN J \& OEHLER U - Neuroendocrine differentiation in prostatic carcinomas: histogenesis, biology, clinical relevance, and future therapeutical perspectives. Urol Int 1999;62(3):133-138.

10. HELPAP B \& KÖLLERMANN J - Undifferentiated carcinoma of the prostate with small cell features: immunohistochemical subtyping and reflections on histogenesis. Virchows Arch 1999;434: 385391.

11. DI SANT'AGNESE PA - Divergent neuroendocrine differentiation in prostatic carcinoma. Semin Diagn Pathol 2000;17(2): 149-161.

12. WEAVER MG, ABDUL-KARIM FW \& SPIGLEY JR - Paneth celllike change and small cell carcinoma of the prostate. Am J Surg Path 1992;16(10):1013-1016.

13. DI SANT' AGNESE PA \& ABRAHAM TKC - Neuroendocrine differentiation in prostatic malignancy. Cancer 1996;78(2):357361.

14. WU JT, ASTILL ME, LIU GH et al. - Serum chromogranin A: early detection of hormonal resistance in prostate cancer patients. J Clin Lab Anal 1998;12(1): 20-25. 
15. JIBORN T, BJARTELL A \& ABRAHAMSSON PA - Neuroendocrine differentiation in prostatic carcinoma during hormonal treatment. Urology 1998; 51(4): 585-9.

16. DIAZ M, ABDUL M \& HOOSEIN N - Modulation of neuroendocrine differentiation in prostate cancer by interleukin-1 and -2 . Prostate Suppl 1998;8:32-36.

17. ALVES VAF, BACCHI CE \& VASSALLO J - Glossário dos principais marcadores imunohistoquímicos. In: ALVES VAF \& MELLO ESM. Manual De Imunohistoquímica. - São Paulo, Sociedade Brasileira de Patologia, 1999. p. 260-270.

18. DI SANT' AGNESE PA \& DE MESY JENSEN KL - Neuroendocrine differentiation in prostatic carcinoma. Hum Pathol 1987; 18(8):849-856.

19. AZUMI N, TRAWEEK ST \& BATTIFORA H - Prostatic acid phosphatase in carcinoid tumors. Am J Surg Path 1991;15(8): 785790.
20. TÊTU B, RO JY, AYALA AG et al. - Small cell carcinoma of the prostate part I: A clinicopathology study of 20 cases. Cancer 1987;59:18031809.

21. HINDSON DA, KNIGHT LL \& OCKER JM - Small cell carcinoma of prostate: transient complete remission with chemotherapy. Urology 1985;26:182-184

22. ABRAHAMSSON PA - Neuroendocrine differentiation in prostatic carcinoma. Prostate 1999;39(2):135-148.

23. SHARPE RW, RECTOR JT, KUSHIN JM et al. - Splenic metastasis in hairy cell leukemia. Cancer 1993;71(7):2222-2225.

24. VARGHESE SL \& GROSSFELD GD - The prostatic gland: malignancies other than adenocarcinomas. Radiol Clin North Am 2000;38(1):179-202.

Received for publication October 03, 2000 